\title{
Investigating Agriculture Teacher Shortage in Secondary Schools in Malawi
}

\author{
Angstone Thembachako Mlangeni (Corresponding author) \\ NR Department, NRC Campus, Lilongwe University of Agriculture and \\ Natural Resources (LUANAR), P O Box 143, Lilongwe, Malawi \\ E-mail: anjtmlangeni@gmail.com \\ Symon Bilesi Chibaya \\ Basics Department, MUST, P O Box 1179, LIMBE, Malawi \\ Estone Ephrone Malinda \\ NR Department, NRC Campus, LUANAR \\ Noel Kapito \\ NR Department, NRC Campus, LUANAR \\ Elijah Aureliano Kamundi \\ NR Department, NRC Campus, LUANAR \\ Nelson Kaperemera \\ Agriculture Department, NRC Campus, LUANAR \\ Frackson Likupe \\ Agriculture Department, NRC Campus, LUANAR
}

Received: Nov. 24, 2014 Accepted: May 8, 2015 Published: May 18, 2015

doi:10.5296/jse.v5i2.6682 URL: http://dx.doi.org/10.5296/jse.v5i2.6682

\begin{abstract}
Agriculture education plays a significant role in Agriculture development which is pivotal to Malawi's economy that employs over $80 \%$ of the workforce and contributes more than $65 \%$ to foreign exchange earnings. For secondary school agriculture to remain relevant to agricultural needs, competent qualified agriculture personnel are needed. Training Needs Assessment (TNA) was conducted to identify and establish training needs of secondary school (SS) agriculture teachers, to establish the gap between demand and availability of SS
\end{abstract}




\section{Macrothink}

agriculture teachers, to identify subject matter deficits in the current SS agriculture curriculum, and solicit suggestions of subject combinations to be included in the NRC Diploma in Agriculture Education curriculum. Information was obtained through interviews of selected SS head teachers, senior education method advisers, principal education method advisers in government institutions, and from heads and members of faculty of education in selected university colleges using semi-structured interview questionnaires. Results indicated that there is a great shortage of agriculture teachers in almost all SS. Forty-four (44) SS out of fifty eight (58) SS sampled in the survey have unqualified or under qualified agriculture teachers which represents $76 \%$. The results also revealed that $75 \%, 59 \%$ and $55 \%$ of DCSS, Private SS and Conventional SS respectively have unqualified agriculture teachers indicating that the problem of unqualified agriculture teachers is most severe in CDSS and Pprivate SS. The shortage has worsened in convention SS (it was less than 20\% in 1995). The shortage is attributable to high agriculture teacher attrition rate (60\%) as more agriculture teachers leave for more lucrative jobs in NGO. Majority of the SS use either unqualified or under qualified teachers to agriculture. The situation calls for more programmes to train agriculture teachers to address the current agriculture teacher shortage.

Keywords: Agriculture teacher, Teacher shortage, Secondary school, Qualified teacher, Unqualified teacher 


\section{Introduction}

As part of growth and capacity building of the nation particularly the education sector, NRC began a process of designing and developing Diploma programme in Agricultural Education with funds provided by Flanders international cooperation agency (FICA). The proposed programme will empower NRC agriculture graduates to qualify as secondary schools Agriculture teachers. It will also accord an opportunity for former NRC graduates teaching agriculture in secondary schools to upgrade with a College Certificate of Education (CCE) or a University Certificate of Education (UCE) and attain a qualified teacher status for agriculture in secondary schools. The programme will provide NRC graduates with a discourse of agriculture education that qualifies them to teach agriculture and other related subjects in secondary schools (Bergenske, 2012). Even though agriculture teacher qualification status does not necessarily ensure effectiveness on the job, NRC recognizes that such agriculture teacher qualification is very vital as it provides and equips the trainee with adequate content, methodologies, techniques, attributes and skills of handling agriculture lessons that guide them to the desired effectiveness (Bergenske, 2012; Futernick, 2002). The initiative will complement efforts taken by other institutions of higher learning such as Domasi College of Education, Bunda Campus of the Lilongwe University of Agriculture and Natural Resources and Chancellor College (University of Malawi). The initiative will also provide an outlet for secondary school teachers to upgrade themselves in view of the fact that Domasi College of Education has had a break in training diploma teachers. Currently, NRC trains Diploma students in Agriculture, Food, Nutrition and Livelihood Security, Environment Management, Irrigation Technology, Land Administration, Animal Health and Production and Basic Studies who work as Extension Officers in various government ministries. Introduction of agriculture education is perceived equip agriculture students/graduates, who are already imparted with in-depth and extended content of agriculture, livestock production, farm business management and farm mechanization courses, with education foundations and teaching methodologies in order to attain a qualified teacher status.

In addition, NRC recognizes that agriculture is pivotal to the country's economy which employs $80 \%$ of the workforce and contributes more than $65 \%$ to foreign exchange earnings. About $54 \%$ of the population lives below poverty line (NSO, 2008). Since education is a catalyst for socio-economic development and for empowering the poor, it is perceived that agricultural sector needs an educated workforce in order to achieve sustainable economic growth, food sufficiency at household and national levels. It is from this perspective that NRC wishes to embark on training diploma students in Agriculture Education to take part in production of quality agriculture teachers who play a crucial role in educating the youths in basic agricultural practices in the secondary school sector, the graduates may spearhead viable agri-business and sustainable developments in addition to training others in the same sector. As a requirement in development of curriculum, NRC used part of budgeted FICA funds to conduct training needs assessment for the diploma in agriculture education programme with the aim of determining the gap between supply and demand of agriculture teachers in the secondary schools with a view of addressing the problem. 
More than $60 \%$ of the population in Malawi is below the age of 20 years. This means that agricultural production is dependent on the youths. One of the goals of the Malawi Growth Development Strategies (MGDS) is to provide an academic basis for gainful employment in the informal, private and public sectors at secondary school level (Futernick, 2002; Farrant, 1977). This will be achieved through training qualified agriculture teachers and technicians who can work in both agricultural training institutions and secondary schools and impart agricultural practices to our youth who actively participate in development activities (Keregero, Dlamini \& Simelane, 2008; Boyd et al, 2009). This underscores the need to develop a unique curriculum for Diploma in Agriculture Education that takes into account sustainable development.

The general aim for coming up with the programme is to increase access and improve agricultural education in secondary schools in Malawi in addition to solving the agriculture teacher shortage problem. The change in policy by government to make agriculture to be a core subject in secondary schools necessitates the need to train more agriculture teachers. In view of becoming part of the solution to the demand for agriculture teachers in secondary schools, NRC conducted a training needs assessment with the following objectives:

- To establish the gap between demand and availability of secondary schools agriculture teachers.

- To identify subject matter deficits in the current secondary schools agriculture curriculum.

- To solicit suggestions of subject combinations to be included in the NRC diploma in Agriculture Education curriculum.

\section{Methodology}

\subsection{Design of Research Data Collection}

Structured questionnaires were developed and administered to controlling officers of Education Division offices, Education districts offices, Malawi Institute of Education, Chancellor College, Domasi College of Education, The Malawi Polytechnic, Lilongwe University of Agriculture and Natural Resources (LUANAR) and Malawi Adventist University (MAU). Focus group discussions were also conducted with secondary school head-teachers, heads of departments and administrators in the sampled districts. In each education district two conventional SS, two CDSSs and two Private Schools were sampled. In addition, directors and senior officers at the Ministry of Education and Science and Technology (MOEST) headquarters and Education Methods Advisory section of the ministry were interviewed. Data that relates to availability and shortages of agriculture teachers in secondary schools were captured through the interviews and focus group discussions.

\subsection{Population Samples}

Questionnaires were administered to a total of sixty (60) secondary schools, five (5) Education Divisions offices, seven (7) institutions of higher learning and MIE. Only 58 secondary schools (97\%), 4 education divisions (80\%), four institutions of higher learning 
$(60 \%)$ successfully responded to the questionnaires and participated in focus group discussions. In addition, all directors and senior officers at the Ministry of Education and Science and Technology (MOEST) headquarters and Education Methods Advisory section positively responded to the questionnaires.

\subsection{Measures}

\subsubsection{Questionnaire for Secondary Schools}

A Questionnaire for secondary school head-teachers, heads of departments and teachers was designed to collect information that relate to:

- State of agriculture teaching in secondary school;

- Number of qualified and unqualified agriculture teachers per secondary schools

- Reasons for agriculture teacher shortages and attrition;

- Qualifications of unqualified teachers teaching agriculture in SS;

\subsubsection{Questionnaires for Training Institutions}

A Questionnaire for training/academic institutions was designed to collect information from deans of faculties, directors of centres and heads of departments about:

- Number of agriculture teachers with diploma and degree qualifications they graduate per year;

- Demand and supply of agriculture teachers

. Number of qualified and unqualified agriculture teachers per secondary schools

- Reasons for agriculture teacher shortages

- Qualifications of unqualified teachers teaching agriculture in SS;

2.3.3 Questionnaire for Ministry of Education, Science \& Technology

A Questionnaire for directors, division managers and district managers in the Ministry of Education, Science \& Technology was designed to collect information from the ministry about:

- Extent of Agriculture teachers' shortage in Malawi;

- Need for qualified agriculture teachers in secondary schools

- Distribution of qualified and unqualified agriculture teacher in Malawi by education divisions, type of school, shortages;

- Qualifications of unqualified teachers teaching agriculture in SS;

In each case the questionnaires were subdivided into sections for each topic. Responses were completed by either ticking a box or writing a few words in spaces provided. Extended written responses were permitted.

\subsection{Data analysis}


Means, graphs and standard error bars for teacher distribution and shortage were worked out using Microsoft excel. Analysis of variance, level of significance and standard error deviations (SED) were computed using SPSS 17.5 version.

\section{Results and Discussions}

\subsection{Agriculture Teacher Shortage in Secondary Schools}

Table 1. Agriculture Teacher Distribution (Survey Data)

\begin{tabular}{llllllll}
\hline Region & SV & SOA & \% SOA & SQAT & \% SQAT & SUQAT & \% SUQAT \\
\hline South & 22 & 22 & 100 & 4 & 18 & 18 & 82 \\
North & 24 & 24 & 100 & 8 & 33 & 16 & 67 \\
Centre & 12 & 12 & 100 & 2 & 17 & 10 & 83 \\
Total & 58 & 58 & & 14 & & 44 & \\
\hline
\end{tabular}

Note: $\mathrm{SV}=$ Schools visited

$$
\begin{aligned}
& \text { SOA = Secondary Schools offering Agriculture Subject } \\
& \text { SOAT = Secondary Schools with qualified agriculture teachers } \\
& \text { SUQAT = Secondary Schools with Unqualified agriculture teachers }
\end{aligned}
$$

As shown in Table 1, 100\% of visited secondary schools offer agriculture as a subject in all the regions of Malawi. It was also observed that as large as $82 \%, 67 \%$ and $83 \%$ of secondary schools in the southern, northern and central regions respectively use unqualified agriculture teachers to teach agriculture. Nationally, on average only $24 \%$ of the secondary schools have qualified agriculture teachers. The observed results are in agreement to data reported by MOEST (EMIS, 2012). The observations imply that majority of the youths are taught agriculture subject by underqualified and/or unqualified teachers in over $76 \%$ of the secondary schools in Malawi. Thus lack of qualified agriculture teachers is continuing to negatively affect delivery (Futernick, 2002) of agriculture lessons as well as impeding meaningful learning of agriculture which has subsequent negative effects on agriculture and education in general.

Table 2. Agriculture Teacher Distribution MOEST HQ Data

\begin{tabular}{lcccccc}
\hline Region & TTA & \%TTA & QTTA & \% QTTA & UQTTA & \% UQTTA \\
\hline South & 603 & 39 & 150 & 35 & 453 & 75 \\
North & 336 & 21 & 119 & 37 & 217 & 65 \\
Centre & 625 & 40 & 159 & 28 & 466 & 75 \\
Total & 1564 & 100 & 428 & 27 & 1136 & 73 \\
\hline \multicolumn{6}{c}{ Note: } & TTA = teachers teaching agriculture \\
& QTTA = Qualified teachers teaching agriculture &
\end{tabular}




\section{Macrothink}

Further analysis of the results showed that there is a large number of teachers teaching agriculture (1564 Agriculture Teachers). However, only less than $27 \%$ of these (428 agriculture teachers) are qualified to teach agriculture at secondary level and the rest $(73 \%)$ are unqualified to teach agriculture at that level. The unqualified teachers have neither demonstrated agriculture subject matter competence nor formal training as secondary school agriculture teachers, hence they are usually ineffective in their lesson delivery (Boyd et al, 2009; Futernick, 2002). Since it is reported that "students who have even two ineffective teachers in a row lose significant ground, which may never be recovered" (Boyd et al, 2009), the observed large numbers of unqualified agriculture teachers (73\%) may have significant disadvantage over the majority of the secondary school youths on their academic achievements in addition to compromising education standards. Furthermore, unqualified teachers' may poorly prepares the youths to take up agriculture/commercial farming as a career when they complete or drop out of school. The finding indicates that majority of youths are taught agriculture in schools by unqualified or under-qualified teachers, hence not well-supported and prepared to succeed and perform better in national examinations (Boyd et al, 2009; Farrant, 1977; Perrott, 1997).

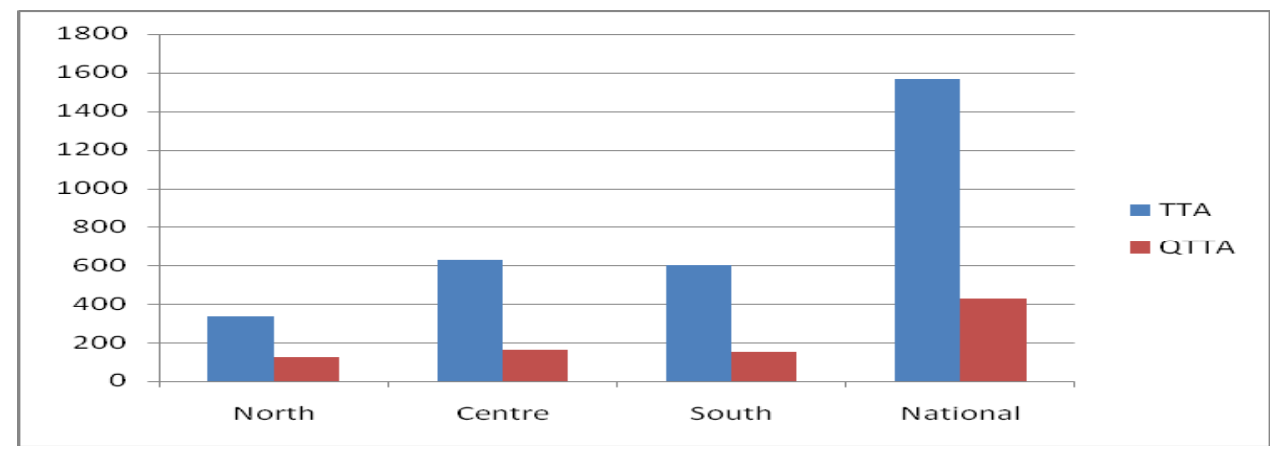

Figure 1 . Teacher shortage and availability by region

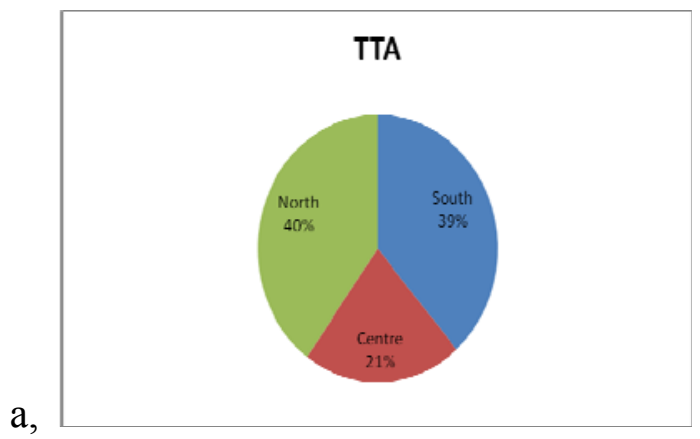

b.

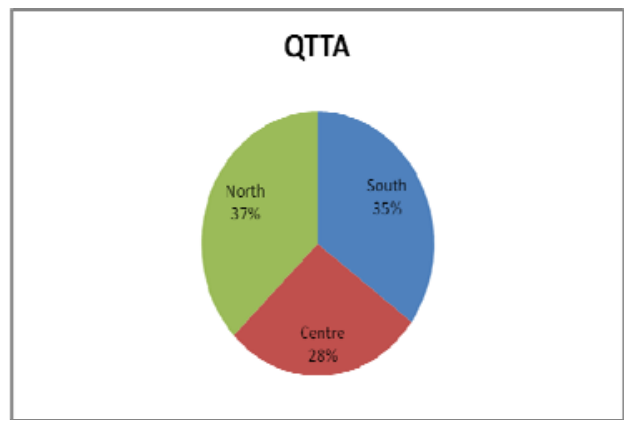

Figure $2 \mathrm{a} \& 2 \mathrm{~b}$. Teacher distribution by region

The results have also showed that secondary schools in the central and southern regions have largest number of TTA of $40 \%$ and $39 \%$ respectively of which only $25 \%$ and $26 \%$ respectively are QTTA (Table $2 \&$ figure $2 \mathrm{a} \& \mathrm{~b}$ ). The large value of TTA is attributed to a large number of education districts and secondary schools in the region. The lower values of QTTA imply that the region is greatly disadvantaged in regard to qualifications of agriculture 
teachers. Least number of QTTA were observed in central region relative to total number of secondary schools available in the region. On the other hand, secondary schools in the northern region have smallest number of TTA $(21 \%)$ of which $35 \%$ are QTTA (Table \& Figure $2 \mathrm{a} \& \mathrm{~b}$ ). Thus, concentration of QTTA is high in secondary schools of the Northern region. The results reveal pattern similar to staff returns of agriculture and qualified agriculture teachers (EMIS, 2014). These results indicate that number of qualified secondary school agriculture teachers is far below the minimum requirement for qualified or credentialed teachers in schools (Boyd et al, 2009; Futernick, 2002). The results further showed that the problem of shortage of QTTA is more severe in the central and southern regions despite having largest number of secondary schools, TTA and arable productive agricultural land. This shortage ill-prepares the youth not only for national agriculture examinations but also for farming career for the majority of the youth who usually drop out at secondary level (Futernick, 2002; Farrant, 1977; Keregero, Dlamini \& Simelane, 2008). Even, though the percentage of QTTA in the northern region is slightly greater than other regions, total value of QTTA (figure 1) is still far much below the minimum requirement (Futernick, 2002; Farrant, 1977; Perrott, 1997) and there is no region that has adequate number of qualified agriculture teachers (QTTA). Therefore, the problem of secondary school qualified agriculture teacher shortage is real and severe and requires an urgent training intervention.

\subsection{Agriculture Teacher shortage at national level}

According to the Ministry of Education Science and Technology (MoEST) reports, there is an acute shortage of agriculture teachers in secondary schools. For instance, there were only 179 qualified agriculture teachers against 1049 secondary schools in 2009 (Domasi report). In 2012, there were 1564 teachers teaching agriculture of which only 428 were qualified (EMIS, 2012) suggesting that majority of teachers (1136 teachers) were either under qualified and/or unqualified. Thus, with an establishment of at least 2 qualified agriculture teachers per school, the shortage of qualified agriculture teachers could be estimated at 1,580, especially that agriculture has been suggested to be offered as a core subject beginning from September 2014 (Daily Times; 2013). Thus driving towards adopting new aims and learning styles (WCAET, 1970; Kasomekera, 1999; Wallace. 1997) at that level. Coupled with natural attrition rate due to deaths, retirement and resignations, shortage of agriculture teachers is worsening every year (EMIS, 2012), hence the need for training corresponding numbers of agriculture teachers. The finding confirm that Malawi is experiencing an acute shortage of qualified secondary school agriculture teachers and may worsen with the introduction of compulsory agriculture subject at both junior and senior levels in secondary schools (Nedi, 2013).

3.2 Distribution of agriculture teachers in community day, private and conventional secondary schools 


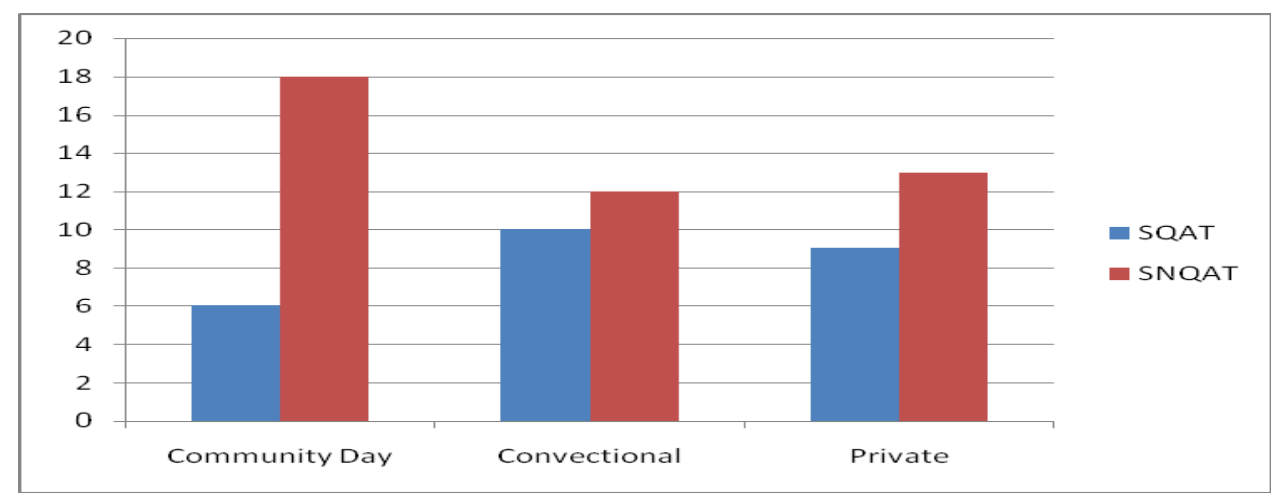

Figure 2. Distribution of agriculture teachers by type of school

As shown in figure 2, it has also been observed that the problem of shortage of QTTA is most severe in community day secondary schools (CDSS) across the regions with SQAT: SNQAT ratio of 75:25 which is significantly different $(p>0.105, \alpha=0.05)$ from the ratios of SQAT: SNQAT in private and conventional secondary schools (59:41 and 55:45). Thus, about 75\% of CDSS offer agriculture subject using unqualified or underqualified teachers which constitute a largest proportion of secondary schools per education district in Malawi. The results also revealed that agriculture is taught in 75\%, 59\% and 55\% of DCSS, Private SS and Conventional SS respectively by unqualified agriculture teachers. The analysis indicates that the problem of unqualified agriculture teachers is most severe in CDSS followed by private schools and then conventional secondary schools. It has been noted that over half of the private and conventional secondary schools have unqualified agriculture teachers (figure 2). Administrators of private schools acknowledged existence of the problem of agriculture teachers' shortage and suggested introduction of distance programme in Agriculture Education as one of the strategies to reverse the situation. As presented above, variations of SQAT and SNQAT in private schools is not significantly different from that of conventional schools $(p<0.001, \alpha=0.01)$. High SNQAT, likely to have negative effects of quality of agriculture education (Boyd et al, 2009; Farrant, 1977; Perrott, 1997), was observed in both private and government conventional secondary schools. The observation establishes the gravity of the problem of agriculture teacher shortage and that it requires an immediate training intervention programme that NRC Campus is seeking to address.

\subsection{Qualifications of Agriculture Teachers Currently Teaching in Secondary Schools}

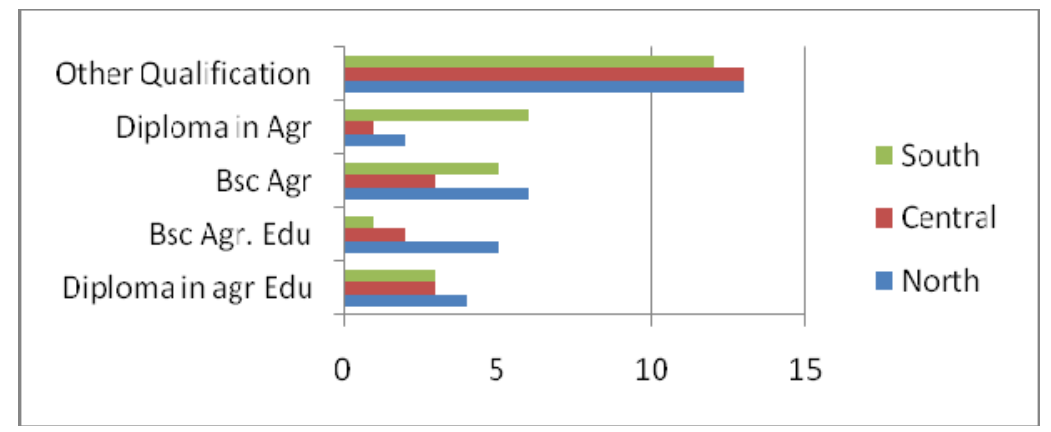

Figure 3. Qualifications of Agriculture Teachers 
Note: Qualified TTA: Agriculture Teachers possessing BSc. Agriculture Education. or Diploma in Agri. Education.

Semi-qualified TTA: Teachers teaching Agriculture possessing BSc. Agriculture or Diploma in Agriculture with no teaching qualification Under-qualified or Unqualified TTA: Teachers teaching Agriculture possessing non-agriculture related qualifications

As shown in figure 3 the survey registered a minimal numbers of qualified TTA possessing BSc in Agriculture education and Diploma in Agriculture education respectively in most secondary schools across the regions in Malawi. Majority of TTA possess other qualifications other than BSc in Agriculture education and Diploma in Agriculture education and teach agriculture subject out-of-their personal interest. The survey further established that there is comparatively a large number semi-qualified well versed with adequate agriculture subject matter but not with agriculture methodology or teaching foundations. In addition, it was observed that agriculture is being taught by special needs teachers and teachers qualified to teach other subjects, who find agriculture economics and farm mechanization topics difficult to teach (Boyd et al, 2009; Farrant, 1977; Perrott, 1997; Wallace, 1997). Specifically, some of these teachers lack not only teaching methodologies but also background knowledge and conceptual understanding of agriculture content. They are usually unable to explain the scientific rationale beyond what is prescribed in the textbooks and if they do so, they do without further clarification (Boyd et al, 2009). The results also shows that there are more qualified teachers in schools in the north followed by the south and then central region which has least number of qualified teachers (figure 3). Thus teachers holding diploma in agriculture and bachelor degree in agriculture need to acquire teaching and instructional methodologies in order to attain a qualified teachers' status (Futernick, 2002; Farrant, 1977; Perrott, 1997). The observation further confirmed the need to start an education programme geared to address the current teacher shortage situation in Malawi. 


\section{Skills lacked by NRC Diploma Graduates}

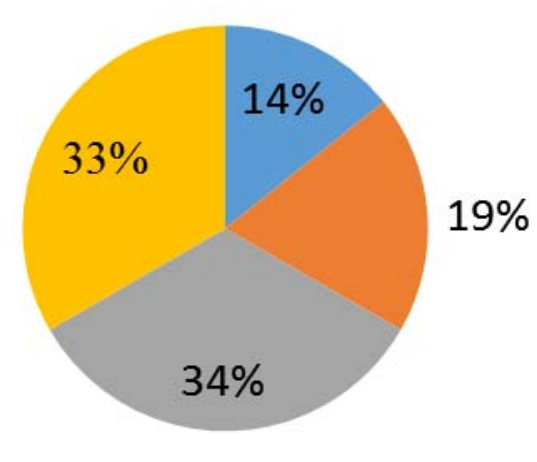

Lesson Planning

Classroom mgt

methodology

content delivery

Figure 4. Skills NRC Diploma graduates lack.

As shown in figure 4, a number of NRC diploma graduates are currently teaching agriculture secondary schools. Slightly a larger number $(50 \%)$ of these teachers seem to have been deployed in the North Education Division. It was also observed that NRC diploma graduates lack some essential as well as fundamental skills related to teaching which include planning, classroom management, teaching methodologies and content delivery skills (figure 4) likely to impair lesson delivery in schools (Boyd et al, 2009; Keregero, Dlamini \& Simelane, 2008). Respondents to our questionnaire indicated that NRC diploma graduates can make very good teachers if they are provided with systematic skills of handling classrooms so that they develop ability to interact with students in class (Boyd, et al, 2009; Futernick, 2002) other than just presenting information without regards to about who is receiving the information (Keregero, Dlamini \& Simelane, 2008; Wallace, 1997).

\subsection{Suggested subject combinations for Diploma in Agriculture to offered at NRC}

Table 3. Suggested subject combinations for Diploma in Agriculture

\begin{tabular}{llllll}
\hline $\begin{array}{l}\text { Subject } \\
\text { Combination }\end{array}$ & South & Central & North & Total & $\%$ \\
\hline $\begin{array}{l}\text { Agri. + } \\
\text { Mathematics }\end{array}$ & 7 & 4 & 1 & 12 & 21 \\
Agri. + P/Sc & 5 & 2 & 2 & 9 & 16 \\
Agri \& Geography & 0 & & 1 & 1 & 2 \\
Agri. + Biology & 8 & 6 & 3 & 17 & 29 \\
Agri. + Home eco. & 2 & 1 & 0 & 3 & 5 \\
\hline
\end{tabular}




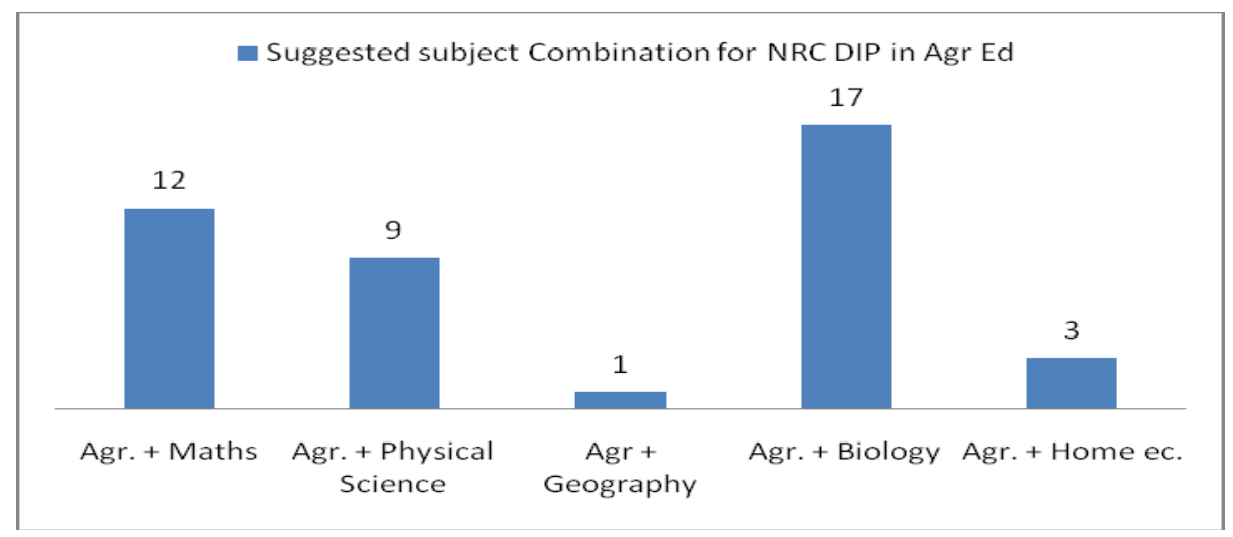

Figure 5. Proposed subject combination agriculture teachers

As shown in figure 5, study results show that majority of the surveyed respondents indicated Agriculture and Biology (41\%), Agriculture and Mathematics (29\%) and Agriculture and Physical science (21\%) (Figure $5 b$ ) as possible teaching subject combination NRC should consider to include in Diploma in Agriculture Education programme and that huge teacher shortage also exist (EMIS, 2012) hence equally needs to be taken on board.

\subsection{Agriculture Teacher Training-perception of Institutions of Higher Learning and MIE}

The results have shown that despite the fact that Bunda campus of the Lilongwe University of Agriculture and Domasi College started degree and diploma programmes in agriculture education respectively, the problem of shortages of qualified teachers still remains. The study revealed that all School Administrator, Secondary Education Advisors, and Desk Officers in almost all Education Divisions who were interviewed agreed that there is an acute shortage of agriculture teachers. It was pointed out that there is need to identify an institution that could also offer agriculture education at both diploma and degree levels. The content of such courses should emphasize on practical teaching and learning and developing positive attitudes towards agriculture student teachers and positively create link from J.C to O-Level agriculture content (Bawden, 1998) which may enhance meaningful learning in students teachers as well as motivate them to teach. Institutions of higher learning and MIE recommended the inclusion of modules and /or subjects indicated in table 4. As shown, institutions of Higher Learning as well as head teachers indicated that unqualified teacher find the following content in agriculture curriculum more difficult to teach especially at senior level in secondary schools: Economics, Agro business \& Entrepreneurship, Seed technology, Irrigation engineering, Aquaculture and Climate smart agriculture. This is agreement with the recommendations made by Falvey and Maguire (1997) and Bawden (1998). It is suggested that topics be included in curriculum for agriculture education programme should be more relevant and responsive to agriculture education and needs and challenges farmers are facing (Kasomekera, 1999; Wallace, 1997). 


\section{I Macrothink}

Table 4. Suggested Content

\begin{tabular}{|c|c|c|c|}
\hline $\begin{array}{l}\text { Suggested Education Foundation } \\
\text { and curriculum courses }\end{array}$ & Frequency & $\begin{array}{l}\text { Suggested Agriculture content } \\
\text { courses }\end{array}$ & Frequency \\
\hline - Theories of education & 4 & - Crop Production & 3 \\
\hline - Teaching practices & 4 & - Animal Production & 4 \\
\hline - School administration & 6 & - Crop Management & 7 \\
\hline - Teaching Methods & 1 & $\begin{array}{l}\text { - Agriculture Research } \\
\text { \& Extension }\end{array}$ & 8 \\
\hline - Philosophy of Education & 5 & - Aquaculture & 8 \\
\hline - Sociology of a School & 3 & - Land Husbandry & 8 \\
\hline - Introduction to Psychology & 6 & - Irrigation Engineering & 7 \\
\hline $\begin{array}{l}\text { Principles of Teaching } \\
\text { Profession }\end{array}$ & 4 & $\begin{array}{l}\text { Environmental } \\
\text { Agriculture }\end{array}$ & 9 \\
\hline - Comparative Education & 6 & $\begin{array}{l}\text { Agribusiness \& } \\
\text { Entrepreneurship }\end{array}$ & 7 \\
\hline - Curriculum Development & 2 & $\begin{array}{l}\text { - Emerging Issues in } \\
\text { Agriculture }\end{array}$ & 6 \\
\hline - Testing and Measurement & 3 & $\begin{array}{l}\text { Food and Human } \\
\text { nutrition }\end{array}$ & 5 \\
\hline - Economics of Education & 6 & $\begin{array}{l}\text { Climate Smart } \\
\text { Agriculture }\end{array}$ & 7 \\
\hline - HIV/AIDS in Education & 6 & $\begin{array}{l}\text { Sustainable } \\
\text { Agriculture }\end{array}$ & 8 \\
\hline - Literacy Education & 4 & - $\quad$ Seed Technology & 7 \\
\hline $\begin{array}{l}\text { - Education Research } \\
\text { Methods }\end{array}$ & 5 & $\begin{array}{l}\text { - Indigenous } \\
\text { Technology in Support } \\
\text { of Agriculture }\end{array}$ & 5 \\
\hline - Career Guidance & 9 & $\begin{array}{l}\text { Ecosystem Approach } \\
\text { to Farming }\end{array}$ & 7 \\
\hline - Leadership Development & 7 & - Fruit Production & 3 \\
\hline - Democracy & 6 & $\begin{array}{l}\text { - Agricultural } \\
\text { Economics }\end{array}$ & 9 \\
\hline - Journalism & 5 & & \\
\hline
\end{tabular}

\section{Conclusions and Recommendations}

The findings indicated that majority of secondary schools ( $76 \%)$ have either unqualified or underqualified agriculture teachers indicating acute shortage of secondary school agriculture teachers and underscoring the need to introduce diploma in agriculture education programme. Majority of the respondents (41\%) proposed Agriculture and Biology as most preferred subject combination. About $29 \%$ and $21 \%$ of respondents indicated Agriculture and Mathematics and Agriculture and Physical science as other preferred subject combination respectively. The respondents proposed an agriculture education programme that respond to challenges that secondary students face in covering difficult topics such as Economics, 
Agribusiness \& Entrepreneurship, Seed technology, Irrigation engineering, Aquaculture and Climate smart agriculture as well as responds to the requirements of a basic commercial farmer. Thus it should be developed in such a way it prepares students who drop out from secondary school along the way to take farming as a business.

The finding provides sufficient grounds for the development of a responsive diploma curriculum for Agriculture Education in Malawi that addresses the raised needs and concerns in shortest possible time. The programme will increase the number of qualified secondary school agriculture teachers. The proposed agriculture education diploma programme will complement efforts taken by Bunda Campus, Domasi College of education and Chancellor College in training agriculture teachers.

\section{Acknowledgement}

The survey was financed by Flemish government through Flanders International Cooperation Agency (FICA) and Natural Resources College, NRC.

\section{Reference}

Bawden, R. (1998). Agricultural Education and Training: Future Perspectives. Paper prepared for the Agricultural Knowledge and Information Systems (AKIS) thematic team in the Rural Family of the World Bank. 1998

Bergenske, L.D. (2012). Lesson study: implications of collaboration between education specialists and general education teachers- Masters of Arts thesis, Humboldt State University. Available on: http://humboldt-dspace.calstate.edu/bitstream.

Boyd, D., Grossman, P., Lankford, H., Loeb, S., \& Wyckoff, J. (2009). Teacher preparation and student achievement. Educational Evaluation and Policy Analysis, 31(4):416-440.

Falvey, L., \& Maguire, C. (1997). The Emerging Role for Agricultural Education in Producing Future Researchers. Journal of International Agricultural and Extension Education, 4(1).

Farrant, J.S. (1977). Principles and Practice of Education. Longman, London

Futernick, K. (2002). Why Teacher Quality And A Teaching Credential Matter. www.publicadvocates.org.

EMIS, (2012) MoEST statistics. Ministry of education and science and technology, Lilongwe.

Hansen, Gary E. (1990). Beyond the Neoclassical University; Agricultural Higher Education in the Developing World, an Interpretive Essay. A.I.D. Program Evaluation Report Number 20. (Washington D.C.: Agency for International Development (IDCA)).

Kasomekera, Z.M. (1999). Mobilizing Development for Agricultural Institutions: Experiences from Bunda College of Agriculture, Malawi. In Proceedings of the Inaugural Conference of the Global Consortium of Higher Education and Research for Agriculture. 
Iowa State University, 1999.

Keregero, K.J.B., Dlamini B. M., \& Simelane, K. (2008). Evaluation of the schools agriculture programme in Swaziland implications for curriculum reform. Available on: http://www.uniswa.sz/

Loukes, H., Wilson, J., \& Cowell, B. (1983). Education: an introduction. Martin Robertson, oxford.

Nedi, L. (2013, July 26). MIE consults on new curriculum. The Daily Times. pp 4.

Perrott, E. (1997). Effective Teaching: A Practical Guide in Improving Your Teaching. Longman, London.

World conference on Agricultural Education and Training (WCAET), Copenhagen, Commission Paper, Number II 1970. Sponsored by FAO, UNESCO, and ILO.

Wallace, I. (1997). Agricultural education at the crossroads: Present dilemmas and possible options for the future in sub-Saharan Africa. International Journal of Educational Development, 17(1), 27-39. http://dx.doi.org/10.1016/S0738-0593(96)00036-3

\section{Copyright Disclaimer}

Copyright for this article is retained by the author(s), with first publication rights granted to the journal. This is an open-access article distributed under the terms and conditions of the Creative Commons Attribution license (http://creativecommons.org/licenses/by/3.0/). 